\title{
Formal Genus of the Value of Justice in Indonesia
}

\begin{abstract}
Sidik Sunaryo ${ }^{1 *}$
${ }^{1}$ Faculty of Law, University of Muhammadiyah Malang, Malang, 65145, Indonesia

*Corresponding author: sidik_sunaryo@yahoo.co.id

\begin{tabular}{|c|c|}
\hline Article & Abstract \\
\hline $\begin{array}{l}\text { Keywords: } \\
\text { Genus; Justice; Formality. } \\
\text { Article History } \\
\text { Received: May 24, 2021; } \\
\text { Reviewed: May 25, 2021; } \\
\text { Accepted: Jun 24, 2021; } \\
\text { Published: Jun 25, } 2021\end{array}$ & $\begin{array}{l}\text { This research aimed to find the formal genus of the value of justice in Indonesia. } \\
\text { As known, justice that holds the sense of plurality universally transcends the } \\
\text { boundary of formality of narrative texts in a normative way. The plurality of the } \\
\text { value of justice that is laden with universality transforms to the genus of the school } \\
\text { of thoughts vis-a-vis justice throughout history. Reduced meaning of justice in the } \\
\text { perspective and the process of legislation is not powerful enough to negate the genus } \\
\text { of justice that inherently represents the fundamental characteristics of justice. The } \\
\text { look of the legislative process attractively reflects the genus of bunger for power } \\
\text { intended to justify ambitions among factions in the domain of democracy. The } \\
\text { formality in the legislation no longer represents the principle of the definition of } \\
\text { the legislation and it is getting further away from the reach of the definition of } \\
\text { aspiration, let alone to become an inspiration of the objectives of the state as } \\
\text { mandated in the constitution. Holistic approach used in this research to find out } \\
\text { the formal genus ofjustice in Indonesia. This research found that religious matters } \\
\text { in the legislation-related authorities have become an acceptable ornament among } \\
\text { the piles of the works of morality. The integrity that has become the genus ofjustice } \\
\text { morality has transformed into a collection of texts hanging all over the wall of the } \\
\text { national parliament. Religions are used as tools of negotiation in the formulation } \\
\text { and the making of narrative texts before they are further transformed into } \\
\text { legislation. Religions and powers in legislation are competing to find theirpoint of } \\
\text { the genus of normativization as expected by each faction. Law came into existence } \\
\text { earlier than expected, leaving bebind its umbilical cord like a prematurely born } \\
\text { soul, the cord through which the values of justice are transferred from its mother, } \\
\text { and these values have the dimension of plurality. Law is born, but since it is } \\
\text { separable from its genus, it does not carry much of the meaning of birth. }\end{array}$ \\
\hline
\end{tabular}
\end{abstract}

(C)2021; This is an Open Acces Research distributed under the term of the Creative Commons Attribution Licencee (https://Creativecommons.org/licences/by/4.0), which permits unrestricted use, distribution, and reproduction in any medium, provided the original works is properly cited.

\section{INTRODUCTION}

Understanding law involves understanding the values/principles implied in the substantive matters of the law, while understanding the law at the surface already gives 
us enough challenge to grab the picture of why a law was made, what was it made for, and what background and influences have served as the bases of the law made.

Law carries an abstract meaning. Thus, its content constitutes a collection of values/principles. Law is lifeless unless they are in the hands of law enforcers who are required to enforce the law with their "power", and this power is capable of controlling whether the law is to survive or die. The understanding and open interpretation established by law enforcers regarding the legal provisions that are explicitly stated have transformed into real law. The failure of law enforcers, if any, may not bring this law to life, stiffening and narrowing the written values carried in the law. That is, whether a law is deemed fair or not depends on the law enforcers.

Satjipto Raharjo (Raharjo, 2010a), argues that the most important nature of the law lies in its rigidity (lex dura sed tamen scripta- law is harsh/stiff, but this is the nature of the written law). When the law came into writing and is forever recorded in a written document, then the attention is dragged to how to use the law as a written document. When a legal process is inseparable from the need for justice-seeking, then we are all facing the legal texts, the text reading, text meaning, and so forth.

Law enforcement that requires the involvement of formal judicial bodies (police departments, offices of prosecutors, courts, and departments of corrections) with all their authorities also begs for an answer regarding where the development of the politics of law is heading (Foreword \& Tollison, 2010).

It is essential to know whether law reform is heading to prevention, which is a bit symmetrically different in the enforcement. Law intended to prevent will tend to require people (Arif, 2008) to serve as a subject of law. This way, the people prosecuted are expected to be far more active than the law enforcers with all their juridical power (Arif, 2008).

G. Peter Hoefnagels (Arif, 2008), stated; a criminal policy is the national organization of the social reaction in crime... a. a criminal policy is the science of responses, b. a criminal policy is the science of crime prevention; c. a criminal policy is a policy of designating human behavior as a crime; $\mathrm{d}$. a criminal policy is a rational total of the responses to crime.

Hoefnagels argues that criminal policy is principally a social policy (members of society) mainly aiming to bring welfare to the people. This welfare would not have existed without the interference of social defence (Erdianti \& Al-Fatih, 2019). The policy made to guarantee the security for the people represents the principle of a criminal policy, since it is implied that welfare will not exist in an insecure society, or vice versa. That is, whoever commits an act that is deemed annoying is subject to just punishment, which is defined by Hoefnagels as penal (causing physical suffering) and non-penal punishment. Law enforcement should tend to lean more on social policy by affecting freedom (Hudson, 2003) of expressing public opinions about the value of just and unjust punishment through the mass media, applying the provisions of 
procedural criminal law, and doing prevention without having to impose criminal penalties on the offender (forgiveness).

The concept of forgiveness is not new in Islam in terms of any conduct categorized into the scope of jinayah. The implementation of forgiveness in Islam can be represented by fine/diyat imperatively on the condition that forgiveness is given by the victim and his/her relatives to the offender of jinayah. This forgiveness can be sourced from Quran and As-Sunnah. In several jinayah cases, customary values of the local communities concerned ('urf) are also considered in giving forgiveness by avoiding the potential of greater damage over merit (maslaba).

Islam, in its perspective, sees the spiritual dimension in humans as in two categories. Taqwa is defined as fearing only God. In this category, humans are seen as individuals to act only according to their conscience, based on which kindness is manifested. Conscience only brings virtue that allows people to see things objectively. People following their conscience in every step of their lives are considered kaffah. On the other hand, people who start their every step with lust are manipulative, and such ill-natured humans may get trapped in greediness.

Islamic values come as a soul into the law enforcement in a judicial process to bring justice. The universality of righteousness and kindness in Islamic values is intended to serve as the basis for maintaining the existence of civilization for all human creatures. Indonesian Constitution asserts that Indonesia was formed to guarantee social welfare, to develop the nation's intellectual life, to protect the life of the people, and to guarantee global security and social justice. The inception of this nation is congruent with the Islamic concept of baldatun thoyibatun (welfare). There is no likelihood for a state to be able to bring welfare without rabbun ghofur (social defence).

The basis of Islamic values (Rahmatan Lil 'Alamin) is defined as giving prosperity to the universe. The principle of the reform of the legal system should be capable of integrating the values of universality that are "genuinely universal", not based on other values that are "temporary". Islam as intended in this study integrates values/principles of righteousness and virtue that are absolutely universal.

The dimension of the values of justice in terms of texts and context are clearly given in the following: 




Figure 1The Dimension of the Values of Justice in Terms of Texts and Context

Interpretation of the narrative text of written norms will give birth to the dimension of formal justice, which is only limited to the formulation of written texts. The narrative interpretation of contexts also produces substantive justice whose substance was sourced from good and righteous values living and growing in the society. The relationship of values built according to prescriptive texts will give birth to the dimension of justice that serves as the basis of social interaction bound in an organic, rational, and contractual relationship. The relationship of values established based on the descriptive context will give birth to the dimension of justice in the foundation of social interaction in an automatic, moral, and emotional way.

Narrative interpretation of texts will give rise to the dimension of formal justice sourced from the relationship of textual values in prescriptive written form, causing social obedience and compliance to be organic-contractual. Law is certain and rigid, and what must or must not be done is written rigidly in legislation. The narrative interpretation of context will produce the dimension of substantial justice sourced from the relationship of contextual values as the moral basis living and growing in the society descriptively. Social obedience and compliance are organic-emotional. Law is just and dynamic since what is good and bad has become the fundamental of moralcommunal value (Rakowski, 1993) growing in line with civilization.

\section{METHOD}

The classic and recurring problem in the quest for justice lies in the meaning of legislation that is getting even shallower structurally or laterally (Irwansyah, 2020). Structurally, the legislative function is merely defined as a celebration of every faction during law-making process, while literally, the subject matters of a legislative product 
have very minimum numbers of references and lack of adequate literacy in terms of either texts or contexts.

A holistic approach in the ideological perspective of the nation as a cultural basis should serve as an entire fundamental of thoughts and conduct in the legislation process (Johnny Ibrahim, 2007). Procedural measures with no morality at the basis of integrity will only lead to futile written law; the law exists in a physical state but it has no basic values of the genus of justice that embody ideological values of the state within which religious values are covered as the main factors in building its performance. The legality and legislation cannot leave their institutions to create a law of high caliber.

\section{RESULT AND DISCUSSION}

\section{The Rationality of The Genus of Justice}

Humans as the most highly valued creatures are responsible to enforce law and justice on earth (L.Tanya, 2011). Humans play their role as leaders in maintaining the cosmic balance of the universe. The cosmic universe is derived from the morality called ilabiah that serves as a self-control instrument against inherent lusts for power. The reality of the genus of power is often too powerful to bend down with morality and rational ethics. Thus, ilahiah as the womb of rational morality finds its relevance. The genus cord serves as a passage through which virtues and righteousness of rational morality receive the spirit of ilabiah that functions as the fundamental and direction in politics of law that is flawlessly just.

The human genus in the perspective of Ilabiah represents a moral core (Kant, 2002) that is entirely rational. Human rationality comes along with mind and morality. Rationality or reasoning (mind) reveals what is right or wrong and what fits life well. Morality is to guide humans to decide the middle way to traverse between two extreme paths to find justice. Morality guides people to pick wasathiyah (the middle way), the choice that gives solid social attitude and mentality in the right portion. The law that has the quality of ilabiah is like a catalyst of elements in extremism, radicalism, and liberalism, all of which serve as the antithesis of the law per se.

Pragmatic radicalism is always linked to the stereotype of moral values of certain religions. Radicalism deemed as crime must also face greater resolution no matter how much the moral values of religion are spoiled due to this step. The state sees there is no connection between the eradication of radicalism and the morality of peace (religion). From the perspective of radicals, radicalism is intended to stand for a certain belief or ideology according to transcendental morals. The moral justification given partially becomes the fundamental of the act and behaviour of the radicals. The inability of the state to guard and guarantee the freedom embraced by the radicals in believing in a moral ideology that is of core importance in their life becomes the justification of the radicalism, and the gaps of such perspectives can be narrowed down 
with experiences (White, 1993) in the exercise of power guided by reasoning and moral, since unspoiled reasoning and moral always pick the middle way to find justice.

The Notion (Bedner, Irianto, Otto, \& Wirastri, 2012) of law is not only restricted to a normative concept, but the cognitions of crimes can be different in political and cultural context. In radicalism, for example, the sense of offense radiated from radicalism can be viewed differently by those having authority in the state (social fact) in comparison to the perspectives of the people or the radicals (social definition). Thus, the substance of the ideology of law dealing with radicalism should put all those perspectives in diametral harmony. Cognitively, radicalism is not always taken as an offense that deserves severe punishment by the people in general, recalling that this deed is possibly due to the subjective and transcendental religious moral motive that justifies radicalism. In terms of the context of those having power at the state level, radicalism is present as a threat that jeopardizes stability.

Law has many dimensions (Irianto, 2009), and understanding law should conform to the social, cultural, economic, and political contextual conditions entirely. The complexity of life humans are living demands a vivid understanding of the objectives of law outside normative texts. Normative texts should be seen as a narration describing what legislators expect in a limited scope. Normative texts do not merely reflect the justification of the expectation of the people although they are subjectively made by the legislators. These texts represent the partial embodiment of legislators in fulfilling the formality of the main tasks of the legislators, as what is set forth in the legislation.

Every law has political, economic, social, and cultural dimensions. This even involves other dimensions such as security, defense, and supposedly morals (religion). The plurality of the substantive matters of law should be made integral within the perspective of the universality of law that describes the vigor of the principle of justice for all, while the plurality of the dimension of law represents the justice of all. Universality does not give rise to plurality and vice versa.

National insight (Dimyati, 2010) of Indonesia should be capable of serving as the principles that lay the groundwork for national law. This national insight can be found in pre-existing values in Pancasila (Five Principles) constituting divinity, unity, deliberation, and justice, and it can further be found in the Preamble of the 1945 Indonesian Constitution constituting 'develop the nation's intellectual life', 'advance general prosperity', 'contribute to the implementation of a world order based on freedom, lasting peace, and social justice'. All these values represent the crystallization of the national insight of Indonesia. Thus, developing the legal systems in Indonesia must adopt all these divine values high above the other values since the divine value should act as the soul and the vigor needed in law-making and enforcement by the state authorities. 
In brief, the rationality of the genus of justice can be explained in the following chart:

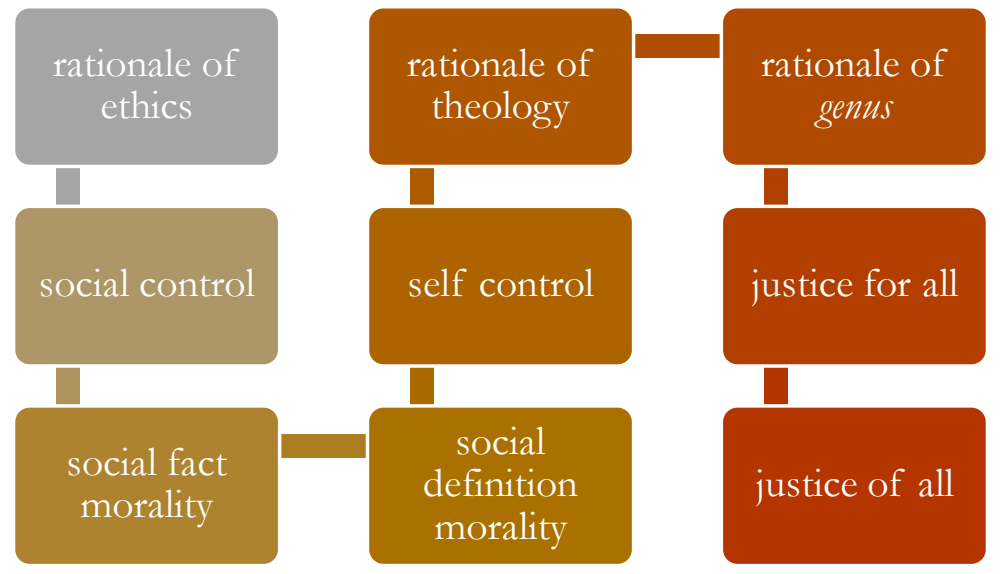

Figure 2 The Rationality of the Genus of Justice

The rational of ethics should be seen as an instrument to control society to ensure that social structure remains on track and appropriate. Behaviour of an individual represents a reaction given to how others behave. Thus, a law exists to control or respond to those taking the wrong way. The rationale of ethics should also be seen as a method to rationalize what is not acceptable, related to what is and is not acceptable in theological values. Thus, it is essential that righteousness and virtues be found in the main genus, God (Meyer, 2010). A just law should come from the message of God (rational genus).

A theological rationale should be taken as an instrument to control individuals/for self-control to ensure that social structure remains within the extent of moral values in the society definitively. The behavior of each individual is a self-perception, defining what is right or wrong. Law is intended to shape the awareness of each individual since social order will not form itself without the contribution of individual awareness in society. Principally, every individual was born and created by God with all his/her dignity and respect embedded in him/her.

Law aiming to control social structure and individuals will bring about the principle of justice for all, while the law whose substance describes moral values of social facts and social definition will bring about the principle of justice of all. Genus rationale of justice is an outlook transcending the line of justice-for-all principle transitioning to justice of all.

\section{Genus Formality in the Legislation Process}

Legal formalization (Raharjo, 2010b) is nothing but to quench rationale desire through partial codification that can give criminogenic effect intruding the written texts and sparking injustice. Unspotted change that triggers disruption can no longer develop the awareness of the people to see the new form of law that should serve as 
an instrument to put the disruption back to normal. Majorly, people are inundated in their desire to call for freedom in all sectors of life blindly without knowing which direction they should face. This nation keeps justifying its desire for power by magnificently producing rules and regulations through legislation. Significant roles in the state administration are only used to extend and widen access through which interference in all affairs of the people can intrude despotically.

The political structure standing as a pillar of the administration of power in the state is reduced significantly in the line of skeptic and provocative narrations. The political process of law has been set as a standard procedure to determine the desire of elites in all sectors to support their own interest. The aspiration process has transformed into provoking legislation and a clash of interest of elites, bringing further to legal oligarchy and power. The term quorum commonly heard in the legislative session is not more than just a room for compromise among factions, and this term is not taken as something to represent the will of the society within the scope of aspiration. The tumult of narrative differences in the legislation process only performs a show laden with anarchy to justify the thirst for power to attack each other.

Formalization (Unger, 1999) in the process of legislation actually has an implication on the structure of doctrines. The formalization of law has brought about shallow doctrines and thoughts of law with the absence of ideology. The formalization of law will stimulate an apology with no clear philosophy and perspective of the law of justice.

Virtuous knowledge (Bertens, 1999) should come from attitudes reflected in the customs of the people carrying the knowledge. Thus, knowledge holds its function and obligation to inspire people to improve their prosperity. The knowledge as the basis in the process of legislation of a norm also demands to be discovered out of the whole values of social life where the norms are made and applied. The primary knowledge in Sunnah [22] constitutes comprehensible verses, the sunnah from the Prophet, and just Faridhah (the knowledge of faraidh/Inheritance Law).

For Moslem, the hadith concerned should be able to show which knowledge could contribute to the improvement of the quality of life both on earth and in the afterlife. Historically, Islam first came to Indonesia, followed by other religions and faiths held by the rest of the people in Indonesia far before and after this nation formed. This historical aspect exists as an issue in terms of the righteousness of religious teachings and faiths within the circle of Moslems. The understanding of Islam is often mixed with cultural tendencies that existed far before Islam came to and was recognized in Indonesia. Even people claimed the truth and purification of their beliefs in their religion, especially Islam, Moslems experienced "kejumudan" in mastering the knowledge that shed light on the problem.

The history of Islam in Indonesia is often closely linked to the phase when Islam came to the archipelago. In classical books, Islam came to the archipelago in 1 Hijri (7 
$\mathrm{BC}$ ), and traced from a particular written document during a Seminar on the presence of Islam in Indonesia held in Medan, Islam came to Indonesia in early 7/8 BC (K.Lubis \& Simanjutak, n.d.).

In the context of the presence of Islam for the first time in the archipelago, Syaifuddin Zuhri (Ali, 1991) asserted that when Ibnu Batutah set foot in Samudera Pasai back in 1345 BC, he was in awe of the ability of Sultan Al-Malik al-Zahir discussing issues in Islam and Figh. Ibnu Batutah also stated that Al-Malik al-Zahir was more than just a king, but he also had his expertise in fuqaha (Islamic Law). From Samudera Pasai, the words of Islam spread further all over the archipelago.

Historically, Islam came to the archipelago earlier than the Dutch in 1602, or this era was commonly known as VOC (Vereenigde Oost Indische Compagnie). Within 350 years, the Dutch colonials took control over social, economic, political, and cultural aspects, law, defence, security, religion, and beliefs all over the archipelago. In terms of the legal systems, the Dutch almost left no room for the development of Islamic Law whose followers grew incredibly vastly.

According to Soepomo (K.Lubis \& Simanjutak, n.d.), a judicial body began to exist in the era of Dutch East Indie, and for religion-related cases, there was also Religious Court which was under the government of the Dutch Colonials, while other courts were established with the initiation of Swapraja (autonomous region) and a customary Head of local community. On 19 January 1882, according to Staatsblad 1882 Number 152, a Religious Court was officially established. Especially in South Kalimantan according to Staatsblad 1937 Number 638 and Number 639, First Instance of Court was established, while Great Qadhi was established for appeal. The existence of Religious Court remained in existence during Japanese colonialism but its name was changed to Scoorioo Hooin and the Religious High Court of Islam was changed to Kikoo Kootoo.

Hamka (Hamka, 1981) confirmed that a messenger from Arab was sent to East Java in 675 BC. This messenger continued his journey as a pilgrim to Kalingga and came back after witnessing how great the influence of Hinduism was in Kalingga. Upon this witnessing, preaching Islam to the states of Malaya did not necessarily involve violence, but it only relied on the intention of Islam per se; "there is no coercion in religion". Arabian colonials started to exist in 684 BC in West Sumatra. And since the $9^{\text {th }}$ century, the names of harbors in the states of Malaya were common in everyone's ears; some named the land Kalah, some others defined Genting Land as Kra, some agreed to call land Kedah or Klang.

Some quotes of history regarding the early existence of Islam in the archipelago, now called Indonesia, aim to indicate that Islam is as old as other religions existing in the archipelago, and this fact can serve as a significant reference of the inception and development of the tradition of Islamic values followed by the people in the archipelago to this time where the nation is commonly known as Indonesia 
On 17 August 1945, the Republic of Indonesia was born, marked with the proclamation of a text signed by Soekarno and Hatta, who later served as the first President and Vice President of Indonesia. On 18 August 1945, the 1945 Indonesian Constitution was into force, and its Preamble states "Independence is a genuine right of all nations.... and by the Grace of God Almighty.... In other words, with the lofty desire of the nation, independence was given under God's grant. This line also implies that Indonesia is a religious nation. There was also a debate involving the Islamic group suggesting that seven words were to be added to the first principle of Pancasila: ...dengan kewajiban menjalankan syariat islam bagi pemeluknya (with the followers' responsibility to practice the sharia of Islam). Although these seven words were not well accommodated back in the time, historically, since the beginning of the independence, there seemed to be an attempt to integrate this Islamic law into the official law of the state, and this tendency is still relatively apparent in the involvement of Moslem in legislative, executive, and judicative bodies. Along with the development of the law, a group of formality streams agreed that Islam was to be officially considered as a formal law of the state entirely with its terminology and nomenclature, while the other group expected Islam to be considered in the formal law of the state but only in terms of its subject matters.

An aspiration of national law reform performed as optimally as possible has adopted legal values that grow amidst the society, including Islamic values living in the society whose members are majorly Moslems. However, it is a great challenge to bring two different perspectives together among Moslems recalling that the important values of Islam have become the formal law of the state. These two perspectives departed from a view considering what is to be adopted as the values of the state's formal law. On one hand, some favored the tradition of Islamic values or figh to be considered. On the other hand, some others agreed that this was the subject matters to be considered. These two different perspectives, however, were present as the dynamic in the national law reform sourced from Islamic values.

The formalization of religious values in the legislative process has become the knot that is binding, the knot giving rise to the law with its genus nature of absolute justice. Not only does this formulation consist of the values of the formality, but it also has the fundamental vigor indicating that the written law that ensures a just legal certainty is the law with its primary characters, a genus of justice. This law has its capability to maintain plurality in intertwined universality.

The formality of the genus of justice in the legislative process is given in the following: 


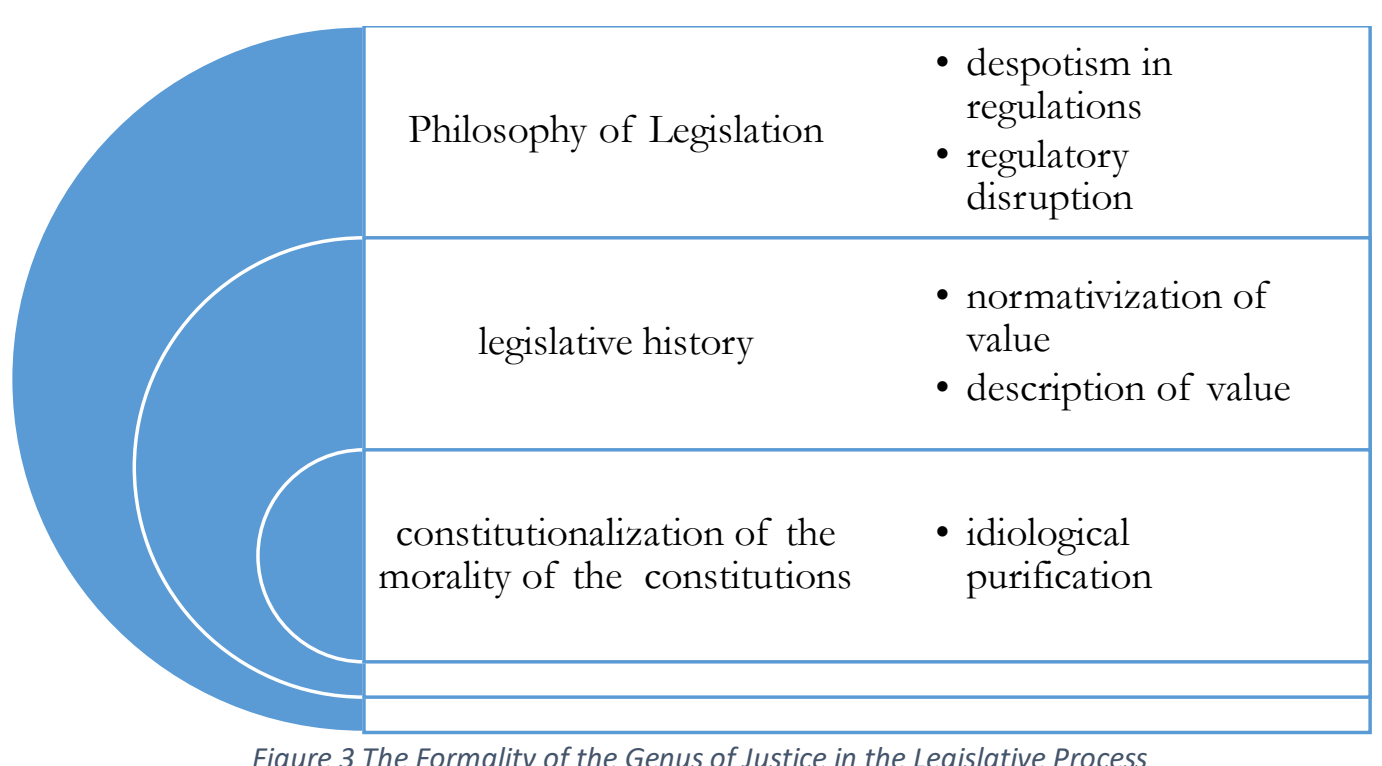

Too rational philosophy of legislation will just give a position to powerful elites where they could freely use their authorities absolutely When this is the case, the subject matter of the law produced will just represent the interest of elites while the people's interest will be greatly reduced due to obstacles to all aspects of their life (despotism). Debating over private and public rights (Hegel, 2001) due to powerful elites' desire as if it would be the justification (Habermas, 2003) of the desire of the people as a whole is certainly unnecessary. Regulatory irregularity is inevitable since the legislative process is no longer linked to ensuring the rights of the people constitutionally (disruption).

The history of regulation aims to elaborate the history of norms descriptively. The shift of meaning of regulation has become an essential part of the minutes of the legislative process of all time. The roadmap of the regulation that constitutes the meaning of values of legislative subject matters has served as guidance to trace back the time that has shifted through the interests and the needs of the generation. Normativization (Schmidtz, 2006) becomes the justification to ensure the constitutional rights of the citizens, and this justification not only intends to reinforce national traditions, but it is also aimed to reach the objective of why a state was formed according to the constitution.

The genus of legislation is an epistemology to ensure the fundamental vigor of the meaning of the constitution of the identity of a state. The constitutionalization of the morality of the state is guaranteed by purifying an ideology. The legislative principle is not merely a process of rationalization of narration of the state grammatically, but it also represents a systematic process to put the morality of the constitution back on track within the scope of ideology in an unspoiled state. The genus of legislation is 
axiology aiming to restore the objectives of law as the fundamentals of the system of development of the state of the law in their orbit.

\section{The Pivotal Core of the Genus of Justice in Legislative Relationships}

The genus of justice serves as a fundamental that leads legislation as expected by people to gaining the legislation. Figuring out how the genus of justice is related to the process of legislation could involve tracing back the thinking concept in vertical and horizontal away. Vertically, it starts from the basic norm as a concept of law (grundnorm) to find out the principle of the meaning of justice as a major intention of a nation to place its initial position as its basis of ideology.

Furthermore, the constitution serves as the reference of the main objective of state administration as the basic structure. Horizontally, the concept of law and the objectives of law as in the formulation of the basic norms and the constitution intended to ensure the objectives are then positioned as a frame of the values of law and justice living and developing in society as the cultural basis.

The main vision brought by the Prophet Muhammad to this world is aimed to fix the civilization of the people. The Prophet's main mission is to enforce justice with the method of amar makruf nabi munkar. These main vision and mission are to give prosperity to all people, while the balance of the universe is still maintained. Peace and social order in terms of positioning Mother Nature as a "home" is the harbinger of the inception of the function of the caliphate of human civilization on earth.

The vision, mission, and the objectives of the messages brought by the Prophet Muhammad are in line with the objectives of Indonesia as stipulated in the Preamble of the 1945 Indonesian Constitution: to develop the nation's intellectual life, to advance general prosperity, to protect the whole people of Indonesia and the entire homeland of Indonesia, and to contribute to the implementation of a world order based on freedom, lasting peace and social justice. All these objectives of the state depart from the spirit of all the principles in Pancasila as the main distinguishing features of Indonesia.

The connection between the prophetic ideology and the ideology of the state has brought about the genus of legislation as an "aqidab" (creed) to embody the norm that guarantees just law. Such a connection is known as state prophetic-minded relationship, a relationship that positions the prophetic matter as a cultural basis through its structural anchor.

\section{CONCLUSION}

Based on the discussion above, this research conclude that religious matters in the legislation-related authorities have become an acceptable ornament among the piles of the works of morality. The integrity that has become the genus of justice morality has transformed into a collection of texts hanging all over the wall of the national 
parliament. Religions are used as tools of negotiation in the formulation and the making of narrative texts before they are further transformed into legislation. Religions and powers in legislation are competing to find their point of the genus of normativization as expected by each faction. Law came into existence earlier than expected, leaving behind its umbilical cord like a prematurely born soul, the cord through which the values of justice are transferred from its mother, and these values have the dimension of plurality. Law is born, but since it is separable from its genus, it does not carry much of the meaning of birth.

\section{REFERENCES}

Ali, M. D. (1991). Asas-asas Hukum Islam (Hukum Islam I), Pengantar Ilmu Hukum dan Tata Hukum Islam di Indonesia. Jakarta: Rajawali Press.

Arif, B. N. (2008). Interest of Criminal Law Policies, The Development of the Drafting of the New Criminal Code (KUHP). Jakarta: Kencana Prenada Media Group.

Bedner, A. W., Irianto, S., Otto, J. M., \& Wirastri, T. D. (2012). Kajian Socio Legal; Seri Unsur-Unsur Penyusun Bangunan Negara Hukum. Denpasar: Pustaka Larasan.

Bertens, K. (1999). Sejarah Filsafat Yunani. Yogyakarta: Kanisius.

Dimyati, K. (2010). Teorisasi Hukum Studi Tentang Perkembangan Pemikiran Hukum di Indonesia. Yogyakarta: Genta Publishing.

Erdianti, R. N., \& Al-Fatih, S. (2019). Fostering as an Alternative Sanction for Juveniles in the Perspective of Child Protection in Indonesia. JILS Journal of Indonesian Legal Studies), 4(1), 119-128. https://doi.org/10.15294/JILS.V4I01.29315

Foreword, E. J. L., \& Tollison, R. D. (2010). In The Pursuit Of Justice Law And Economics Of Legal Institutions. United States: Palgrave MacMillan.

Habermas, J. (2003). Truth and Justification. Cambridge: The MIT Press.

Hamka. (1981). Sejarah Umat Islam. Jakarta: Bulan Bintang.

Hegel, G. W. F. (2001). Philosophy of Right. Ontario: Street South Kitchener.

Hudson, B. (2003). Justice in the Risk Society Challenging and Re-affirming Justice in Late Modernity. New Delhi: SAGE Publications London.

Irianto, S. (2009). Hukum Yang Bergerak Tinjauan Antropologi Hukum. Jakarta: Yayasan Obor Indonesia.

Irwansyah. (2020). Penelitian Hukum: Piliban Metode \& Praktik Penulisan Artikel (A. Yunus, ed.). Yogyakarta: Mirra Buana Media.

Johnny Ibrahim. (2007). Teori dan Metodologi Penelitian Hukum Normatif. Malang: Bayumedia.

K.Lubis, S., \& Simanjutak, K. (n.d.). Hukum Waris Islam. Jakarta: Sinar Grafika.

Kant, I. (2002). The Critique Of Practical Reason Translated Thomass Kingsmill Abbott. Indianapolis: Hackett Publishing Company.

L.Tanya, B. (2011). Penegakan Hukum Dalam Terang Etika. Yogyakarta: Genta Publishing.

Meyer, L. R. (2010). The Justice of Mercy. Street Ann Arbor: University of Michigan Press.

Raharjo, S. (2010a). Progressive Law Enforcement. Jakarta: PT. Kompas Media Nusantara.

Raharjo, S. (2010b). Sosiologi Hukum Perkembangan Metode dan Pilihan Maslah.Genta. Yogyakarta: Genta Publishing.

Rakowski, E. (1993). Equal Justice. Clarendon Press. 
Schmidtz, D. (2006). Elements of Justice. Cambridge: University of Arizona. Cambridge University Press The Edinburgh Building.

Unger, R. M. (1999). Gerakan Studi Hukum Kritis. Jakarta: ELSAM.

White, G. E. (1993). Justice Oliver Wendell Holmes Law and The Inner Self. New York: Oxford University Press. 